International Journal of Social Science and Economic Research

ISSN: 2455-8834

Volume: 05, Issue: 06 "June 2020"

\title{
BENEFITS OF DIGITALIZATION IN INTERNATIONAL LOGISTICS SECTOR
}

\author{
Dr. Hasan BARDAKÇİ \\ Harran University, Siverek Applied Sicences Faculty, International Trade and Logistics Department, \\ Şanlıurfa, Turkey, (ORCID ID: 0000-0002-6181-3115) \\ DOI: 10.46609/IJSSER.2020.v05i06.009 URL: https://doi.org/10.46609/IJSSER.2020.v05i06.009
}

\begin{abstract}
For the development of the country's economy, the logistics sector must be at a level that can compete in the international market. This requires being higher than the logistics level of the foreign market. This can be possible by using the latest technologies or by producing new technologies. Especially logistics aiming to respond to the needs of the customers in the fastest way; it has become a strong sector with advanced technological structures and increasing demands of consumers with the effect of globalization. As a result, businesses had to follow closely the innovations on the agenda to keep profit margins and customer satisfaction high.

In this study, the digital logistics process and digital structures used in the logistics industry are mentioned. The benefits of digitalization are discussed in detail. Information about the future of digital logistics is provided.
\end{abstract}

Keywords: New Technologies, Globalization, Logistics, Foreign Market, Benefits

\section{INTRODUCTION}

With the most basic explanation of digitalization; It is the replacement or replacement of existing resources with digital products in order to provide the highest level of efficiency with the lowest physical effort. In the past, all transactions were handled with documents with invoices. Documents were filed and stored in archives. With the advent of the Internet, all transactions began to be stored in computer memory. Access to information was quick and easy with the use of the Internet. We can define digitalization as a combination of our life and technology.

If we define digitalization as the logistics dimension, it is the use of the activities, products and processes with the technological possibilities in order to increase profitability, to compete in the global market, to increase efficiency. One of the most important factors in the logistics process is digitalization. The integration of businesses with digitalization is necessary to sustain their 


\section{International Journal of Social Science and Economic Research}

ISSN: $2455-8834$

Volume: 05, Issue: 06 "June 2020"

existence. Because of the benefits of digitalization to the business, businesses mostly invest in technological devices. Encourages the use of advanced production technologies that help optimize in digitization production processes. Businesses make most of their large investments in digital devices in order to survive. Investing in the latest technologies does not guarantee achieving the targeted changes. Companies may need to focus on new business models, redesign operating models, develop systems to attract and promote digital capabilities, and design new measurement mechanisms to track success

Digital logistics is created not only in the developing basic industry, but also in the development of the modern economy, which plays an increasingly important role in the national economy and social development. digitization for Turkey, it is important to be competitive in the global value chain. maintain competitiveness in the global value chain and Turkey needed to focus on digitalisation to improve. When the conversion is complete, this is a breakthrough in global competitiveness and Turkey does not do investment to digitalize the position in global competitiveness will be reduced. Such a change will give an advantage to developed countries.

\section{LOGISTICS}

It shows the existence of human needs and its existence in logistics. People need logistics to achieve their needs. It would be wrong here to describe logistics as merely a means of transportation. Logistics, planning and transporting and storing the materials, service and information flow in both directions (both forward and backward) in an effective and efficient way from the starting point of the raw materials to the end point where the product is consumed, in order to meet the needs of the customers, implementation and control. (Akşahin, 2014, p. 8)

There are many definitions about logistics. But in the shortest expression, logistics includes planning of the product, storage of the product, transportation of the product, in short, all kinds of activities related to the product, starting from the provision of the product to the delivery point to the consumer.

\subsection{Industry 4.0}

Many developments have occurred in the field of industry until today. As the developing technology is not sufficient for the needs of people, the concept of industry has emerged. For example, an iphone brand increases its demands with its features. It develops phones to meet the needs of customers at the highest level in every phone it releases.

The concept of Industry 4.0, which was mentioned for the first time in the fair held in Hannover, Germany in 2011, is defined as the project of equipping the traditional production industry of Germany with computer-oriented work and digitization with high technology. (Karabaş, 2019, p. 3) Since 2011, the concept of industry has developed in all sectors. The industrial revolution, 


\section{International Journal of Social Science and Economic Research}

ISSN: $2455-8834$

Volume: 05, Issue: 06 "June 2020"

which started with the invention of the first steam engine, has constantly improved and the industry 4.0 revolution has occurred (Adigüzel, 2019, p. 3-11).

\subsection{Globalization}

The concept of globalization is a concept that includes topics such as the spread of economic, political and social relations between countries, elimination of ideological distinctions, better definition of different cultures, and inter-country relations. (Kurtalan, 2009, p. 6) We can define globalization, also known as globalization, as the use of goods or services produced within the country in the whole world market through export. Changing market and competitive conditions with the influence of technologies have affected businesses in the globalization dimension.

The biggest effect of globalization is removing the borders in international trade. In this way, businesses can act more effectively in the global market and compete in the global market.

Enterprises must constantly innovate and develop in order to achieve success in a competitive environment. It must have a higher level of infrastructure than its competitors in the global market. This is possible by following the technology closely and applying it to the business.

\subsection{Technology}

We use technology in almost every field. Technology is the results that man achieves by using both his own and social reason and memory to control and change nature, society. (Sarkaya, 2014 , p. 2) Technology generally arises from a need. It is invented as a result of these needs. In other words, we can say that technology is the components and tools that offer solutions to social problems. Technology, which has a very wide scope, is called to transform a form of information to be presented to human life.

Technology has great benefits to many sectors (Bardakçi, 2019, p.69). For example, health, education, trade, etc. are the areas where technological tools are used. The technology used in the field of trade provides an advantage to the company among its competitors. The technology used in education increases the permanence of education and provides easy access to information. Technologies used in the field of health, on the other hand, provide healthier service to the patient. And more these sectors have many benefits.

Technology is indispensable for the development of a country. Looking at developed countries, it is seen that technology is used effectively and in all areas.

\section{HISTORICAL DEVELOPMENT of DIGITALIZATION}

The first change and development in history started in the 17th century with the transition of people from gathering to agriculture. The reason for moving into settled life is domestication of animals and their use in agricultural works. Domestication of animals revealed production and 


\section{International Journal of Social Science and Economic Research}

ISSN: $2455-8834$

Volume: 05, Issue: 06 "June 2020"

transportation. As a result of production, the population has increased and urbanization has started.

This situation continued until the 18th century. In the 18th century, the first steam machine was produced with the industrial revolution. This industrial process, which started in England in the 1760s, spread throughout Europe. Scientific changes in the 16th and 17th centuries, with the developments in the field of maritime, the discovery of new places and the Industrial Revolution triggered by the technology have made major changes in the cultural and economic area. (Sedefçi, 2018, p. 2) With the production of the steam machine, the period based on agriculture started to become mechanized. Previously, manual work was started with the machine. Production increased with the transition to production. Factories were established with the increase in production.

The invention of the steam machine has led to major developments in other sectors. Transportation industry has been developed by using steam, coal and iron as raw materials. The products produced with the development of the transportation sector have been opened to the global market.

With the development of technology and the production of new machines, the second industrial revolution has begun. Previously, transportation was done by wheelbarrows or overhead. This situation increased both time loss and labor force. This situation started to change due to the new transportation methods developed in the USA in the mid-1950s. Pallets as a universal loading vehicles and forklifts, a solution of the US military's huge transportation need during the Korean war, were introduced during this period. This new technology is adapted to German conditions. (Kasımoğlu, 2018, p. 4) With the invention of loading vehicles, stacking vehicles have also started to develop. This period, which we can also call the era of mechanization, has shown its effect in many sectors. Machines used in transportation, banking, communication and many other fields have increased the quality of life of the people.

The 20th century is the period when international trade developed most rapidly. The increase in production increased the need for labor and intense working conditions were created. As a result of this development, labor costs and material prices increased. In this period, businesses have aimed at efficiency in all areas only in the field of production. The storage area has come to the fore with the rationalization potential. The first automatic 20 meter high ceiling warehouse areas were built in Germany in 1962. The emergence of such storage areas has led to a period of progress in the development of rack feeders that are removed on rails or advanced at ground level. (Kasımoğlu, 2018, p. 4) The expansion and effective use of warehouse areas have enabled the products to be stored and supplied in a good condition. 


\section{International Journal of Social Science and Economic Research}

In the developing market, consumers were now demanding better quality goods. Also, the timely and sound delivery of the product was also important criteria. Considering these criteria, innovations were tried to be created in production, storage, order and transportation. In this period, material monorail systems such as electric monorail systems, Automatic Guided Vehicle (AGV), Automatic Storage and Retrieval Systems (AS / RS), (Automated Storage / Retrieval Systems) and long product storage systems it was seriously affected by the emergence of new technologies. (Kasımoğlu, 2018, p. 4)

The richness of connectivity and information resulting from the emergence of the Web contributed to an increasingly dynamic business environment and market, and caused a flexible and collaborative conceptualization from a static, closed and competitive business model in traditional business thinking. The use of the web network with advanced technologies increased production and created new markets. The combination of the Internet with the machines has produced new software, and its development has affected communication, transportation and, as such, international trade. Computers started to be used in many areas in human life and provided access to information and easy access to needs. The emergence of the first usable microprocessor in 1972 can be called the benchmark of the third industrial revolution. Microprocessor based technologies were first used with AS / RS for functions such as control, positioning and data transfer as well as error reporting. Later, these began to be used to control upstream and downstream flows in storage. (Kasımoğlu, 2018, p. 4)

Using microprocessor data to monitor and control the products has accelerated the data flow. At the end of this period, we see that the storage systems have developed significantly.

When it was seen that the developing technologies did not meet the needs sufficiently, the technologies started to be developed. These technologies have been developed faster and with higher potential. These technological tools were developed in such a way that human power was not needed and this period was called Industry 4.0. The concept of Industry 4.0 identified five areas of technology that are considered to be within the domain. Embedded systems, smart objects, CPS, Intelligent Factory, robust networks, cloud computing and IT security are the technological cornerstones for future production and success. (Arkan, 2018, p. 8)

The process that started with steam power has been effective in forming today's world. And this process takes us to the future.

\section{USING DIGITALIZATION IN LOGISTICS AND SUPPLY CHAIN}

The developing digital technology has ensured the removal of the borders in the world trade, the increase of competition, the necessity of delivering the right product to the customer at the right time, at the best price and at minimum cost. Companies have discovered logistics as the most effective competitive element in increasingly competitive conditions. Regardless of the quality of 


\section{International Journal of Social Science and Economic Research}

ISSN: $2455-8834$

Volume: 05, Issue: 06 "June 2020"

the product, logistics should be taken into consideration. Digitalization attracts businesses like a vortex and provides assistance in all areas. Technology is indispensable for businesses in order to keep up with global markets that are constantly changing and developing and to achieve success. Businesses must keep themselves constantly open to innovation during this change process.

Companies use digital opportunities in almost every field. Because digitalization speeds up the logistics activities of companies and enables them to use this process effectively and efficiently. Thanks to digitalization, the problems that may occur in the logistics process are minimized and offer instant solutions.

Since the focus of the companies is the customers, it would be better to use the technology in the areas that more customers can access. Businesses are currently using technology mostly in transportation systems in warehouse systems.

It is important to use some technological applications for an effective and successful digital logistics. These applications are;

Plan Resource planning: resource planning is the planning of the business provided that it uses all its resources efficiently and its application in all business activities. Resource planning provides the business with profitability, efficiency and efficiency in business processes, ensuring effective communication with the customer and the manufacturer.

Warehouse systems: warehouses are an important unit for businesses. Effective use of warehouses provides an advantage to the business in a competitive environment. Equipping warehouses with technological systems reduces the labor costs of companies, minimizing errors in warehouse goods counts.

Transport systems: Transport systems developed by digitalization can see companies where their vehicles are using GPS technology. This system, which is also offered to the customer, can follow the customer's product.

Security of information: One of the possibilities provided by technology is to store the data of businesses in computer environment. The need to protect information in computer environment has also emerged. Due to the cybercrime experienced today, businesses must keep their data in a safe environment. The transfer of information to people who commit cybercrime can put the company in a difficult process.

In today's business environment, retailers and manufacturers face increasing complexity in managing the supply chain. As complexity increases, these retailers and manufacturers see technology as a tool to help manage supply chain flows. Generally, managers expect a particular technology to increase efficiency by paying little attention to whether the partner firm is ready for technological implementation. 


\section{International Journal of Social Science and Economic Research}

ISSN: $2455-8834$

Volume: 05, Issue: 06 "June 2020"

Efficient logistics and supply chain management are provided by using efficient information technologies. The emerging trend worldwide is the digital supply chain. Mobile logistics tools represent the interface of information technologies in the supply chain. In the transportation of goods or services from the production point to the delivery point, it is possible to perform the services provided to the customer in the best way and to increase the logistics performance with the digital supply chain.

The application of information technology is critical to the logistics and innovation of logistics equipment and technology.

It is an important trend for domestic and foreign large-scale businesses to reform modern logistics management and adopt central logistics management.

Thanks to the experience and information technology of developed domestic and international businesses, the economic benefits of electrical network construction can be improved by combining the logistic management activities between entry and exit through the integration of logistics management activities and the integration of logistics supply functions and the inclusion of the internal supply chain.

\subsection{The benefits of digitalization to business}

There are winds of change all over the world that radically affect daily life and working types of work. This change is happening incredibly fast. The digital economy offers new opportunities for humanity. Digital technology opportunities bring the concept of digital economy with it.

Companies that will benefit from technology in the 21 st century will be able to transform fast developing technology into a more efficient and economical logistics service. Therefore, companies should be established on a fast and reliable technological infrastructure in internet and intranet-based technologies. In this century, it is impossible to provide convenient and efficient logistics services without using digital technologies.

Innovation is one of the important methods for logistics entrepreneurship to reach basic competencies. Logistics enterprise can survive and develop only if it is continued with hard market competition with innovations and then reaches core competence.

Digitalization has many benefits for businesses in every respect. Let's examine these benefits in separate sections.

\subsection{Benefits of Digitalization to Production}

Digitalization offers business processes that are used more effectively in the production and marketing activities of businesses. Increasing customer needs and advances in technology force companies to make permanent investments for the success of their logistics functions. 
Logistics technological systems using both internet and electronic commerce applications provide significant cost savings and also enable physical procurement activities to be activated as a system. By activating its commercial activities related to physical supply resources through innovations and improvements in information technology, businesses realize three simple management principles known as speed, flexibility and expectation.

Far from traditional logistics management tools, new logistics technologies lead to a strategic cooperation between enterprises with their expanding physical supply resources, and this enables companies to gain strategic advantages in areas such as production, stock, communication and transportation by directing them to their resources.

Production technologies benefits to companies;

Responds to customer requests instantly.

Reduces inventory costs.

Lowers labor costs.

Improves the quality of the product produced.

Minimizes the error rates that occur during the production process.

Creates competitive advantage in the global market.

Provides ease in product development.

It shows a decrease in product cost.

It increases the efficiency and profitability of the business.

It saves time.

It provides the opportunity to intervene in the errors that may occur in production.

It ensures the security of the data by keeping the production data in computer environment.

Provides cheap raw material supply.

\subsection{The Benefits of Digitalization to Marketing}

In the digital marketing concept of the 21st century, logistics quality can outweigh the product itself in the competition between companies. Now, manufacturing companies place the same weight on fast and efficient logistics services with product and new production techniques. 


\section{International Journal of Social Science and Economic Research}

ISSN: $2455-8834$

Volume: 05, Issue: 06 "June 2020"

As a result of the digitalization in the global market, described as another version of the industrial revolution, the existing marketing system needs to be revised to establish it. For this reason, it can be said that businesses that do not use the high potential of technology in the business world and do not develop their marketing strategies may enter a process of extinction. As a result of this guidance, businesses will lose their competitive advantage over commercial enterprises. Therefore, it is very important to create new competitive marketing strategies necessary for an effective sales profile.

The function of the logistics applications framework is the link of the production and marketing activities of businesses. The relationship between the internet and marketing in the digital environment should be used especially as a new distribution channel function. Orders obtained through order forms on the websites filled by customers lead to sales transactions to be made predominantly on the internet. In this process, a new distribution strategy should be developed instead of a distribution structure. It will simultaneously reach a huge consumer base and will include new mediators. An effective and effective physical distribution subsystem must meet the needs of customers.

In physical distribution functions, marketing activities are implemented interactively.

This is one of the biggest advantages of using the internet as a marketing tool in information technology, ensuring that consumers are directly influential in the production of goods and services.

Businesses with a vision of marketing information system try to increase their productivity and profitability by making rational decisions in their marketing channels. The benefits of digitalization to marketing are;

Modern marketing activities ensured that the goods and services produced are delivered to consumers in the right situation and in the right place.

Compared with traditional marketing activities in processes such as taking orders, evaluation and classification, modern marketing systems increase the efficiency of logistics activities and offer a time-saving advantage.

It provides the opportunity to reach a large customer base.

New Modern marketing systems cost less and operate faster than traditional systems in the flow of larger orders to buyers through logistics technologies.

Provides a competitive advantage to the company. 


\section{Minimizes advertisement costs.}

The new communication network created by information technologies in the environment, which enables people to live in interconnected market economies, offers opportunities to reach not only customers but also suppliers and business partners.

Improves the service quality of the business.

\subsection{Benefits of Digitalization from the Consumer Perspective}

It is important to offer a higher level of satisfaction and prosperity for customers. In a new economic system that is open to continuous innovations brought by the digital environment, entrepreneurs with a small amount of capital benefiting from information technology have the chance to succeed by using the features of the new system as speed, efficiency and customer priority. Moreover, the fact that a consumer is in contact with businesses at all stages, starting from the planning of products and services, is produced as an idea before production, and continuing to deliver products and services leads to maximizing the expectations of customers.

It should not be ignored that establishing healthy and long-term relationships with consumers depends on the timely and timely fulfillment of buyer orders. Accordingly, harmonizing the buyer order data of the enterprises with the physical distribution processes will be a factor providing competitive advantage between the buyer demand and the enterprises.

The benefits of digitalization for consumers are as follows;

Provides the use of cheap and fast information technology.

It provides an instant and easy access to new products.

The consumer can easily reach the entire market.

You can see the product on the web without purchasing it.

The customer saves time by seeing the product on the internet.

Besides shopping places, it provides the opportunity to purchase in the home environment or from where it is located.

\subsection{Benefits of Digitalization for Distribution}




\section{International Journal of Social Science and Economic Research}

ISSN: $2455-8834$

Volume: 05, Issue: 06 "June 2020"

Considering the development of a suitable and optimum transportation system and the competitive advantages they offer, another point that should be emphasized is the determination of transportation vehicles and the use of technology in logistics management.

The link between logistics processes requires a high level of coordination in logistics functions, and ensuring coordination between functions depends on regular and complete exchange of information between parties within logistics activities.

Logistics functions that express the flow of goods and services through the distribution channels are the activities that must be carried out to ensure that the physical flow process is carried out in a cost-effective and efficient manner. Considering the implementation of logistics activities in the context of the whole process, the entry of raw materials, semi-finished products and other inputs into the consumer as final input takes place under the effectiveness of business logistics.

Trouble-free delivery on time in the digital economy is the common goal of both organizations and customers. Therefore, benefiting from the relationship logistics model in the logistics system will increase the control and coordination in logistics activities and cause the company to gain competitive advantage. The relationship logistics model will systematize the logistics activities of the institution and minimize the possibility of errors.

Performance in the corporate logistics system consists of logistics targets in the distribution channel. The goals set in logistics management are the main goals that direct logistics activities.

Distribution and logistics are considered as important as the high quality standards of the product. Providing the most convenient and fastest distribution that takes a product from the production line and brings it to the customer's shelf is considered as important as producing that product.

When a tendency to logistic rules is shown in a relationship, functional members can be covered by market coverage, customer satisfaction, etc. It shares common and complementary goals. In addition, another point that should not be taken into account is that all members in the distribution channel agree.

The benefits of digitalization to distribution;

It saves time.

Lowers labor costs.

Increases customer satisfaction. 
Creates competitive advantage in the global market.

It provides the advantage of learning where the product is with the product tracking system.

It provides the determination of the route that the product will go to the point of delivery.

Offers a safe environment for delivery.

\subsection{Benefits of Digitalization to Storage}

Storage is another area considered as one of the starting points of logistics activities. This should be implemented in accordance with high-tech distribution processes related to the storage of goods inside and outside the enterprise using computer communication systems. While preparing warehouse policies and strategies, it should be planned that the selection process of the warehouse location, which combines new technologies and company infrastructure in an ebusiness environment, has a minimum cost and maximum efficiency to create a competitive advantage against competitors.

Logistics inputs include the necessary raw material resources, human and other capital resources, which contribute to the efficient transport of goods and services to the consumers of businesses. These logistics inputs may differ between functions in relation to the logistics activities implemented. In addition, another point required for the logistics activities to operate is the commitment of each function member to the resources agreed at the beginning of the exchange relationship.

Enterprises that need to establish a technological balance can achieve optimum inventory levels by taking into account the cost, demand, product features and competitive conditions among the raw material sources according to stocks, sales and production, stock quantities and quantities.

The benefits of digitalization to storage;

Facilitates the counting of goods.

It saves space.

Provides easy transportation and transportation of products.

Reduces losses in raw material or product order. It prevents the purchase of excess raw materials or products. 
International Journal of Social Science and Economic Research

ISSN: 2455-8834

Volume: 05, Issue: 06 "June 2020"

It provides the opportunity to instantly respond to the orders of the consumer.

It facilitates inventory management.

Lowers labor costs

\section{CONCLUSION}

With the increase in the international trade volume, it started to show itself in technological innovations. Countries have made many contributions to the logistics process by developing new technological tools. These technological innovations provided great convenience in the transportation of goods. On the other hand, these technologies also provide production companies the opportunity to provide quality products.

Today, technology is making its name in many sectors. When work done with manpower met with technology, it was started to be done through robots and web software. This change has greatly affected people's lives. So much so that it has made it impossible to do business without technology, which has connected people's daily lives with technology.

To be successful in the global market, first of all, it is necessary to be rich in digital possibilities. The more we apply digital possibilities to our business, the more we are successful in global trade. In fact, it is not enough to have digital possibilities to be successful. It should also be used by experts in the field of digital systems control. Digital systems give the business a costeffective marketing opportunity.

Digitization in logistics also affects customer demands. It provides easy access to products with the participation of e-commerce in our lives. Comparison of the customer with the other products led the businesses to focus on customer focus. Formerly oriented targets have been replaced by customer orientation and market survival. In order to reach these goals, the product portfolio and quality should be improved and the services provided to the customer should be fulfilled in the best and fastest way.

As mentioned above, digital tools affect our lives, national economy and businesses. When we look at the study in general terms, it is seen that digitalization has many benefits to the logistics process. It is expected that logistics will provide a faster and higher quality service with increasing digital tools. Of course, this is not possible without digital systems. 


\section{International Journal of Social Science and Economic Research}

ISSN: 2455-8834

Volume: 05, Issue: 06 "June 2020"

\section{BIBLIOGRAPHY}

Adıgüzel, S. (2019) Lojistik 4.0. Nobel yayın evi, Aralık. Ankara

Akşahin, B. (2014). Tedarik Zinciri Yönetiminde Gıda Sektöründe Meydana Gelen Bekleme Zamanlarının Kısaltılması. İstanbul.

Arkan, Ö. (2018). Endüstri 4.0 Kavramı ve Endüstri 4.0 Dönüşümünün Üretim Maliyetlerine Etkisi Üzerine Bir Vaka Çalışması: Bebek Bezi Üretimi. İstanbul.

Bardakçi, H. (2019) İnovasyon ve Öz yeteneğe dair her şey. Cinius yayınları. Ekim. İstanbul

Karabaş, P. (2019). Endüstri 4.0 \& Dijital Dönüşümde Çalışanların Değişime Açıklığı İle Yöneticilerinin Liderlik Tarzları İlişkisinin İncelenmesi. İstanbul.

Karaduman, İ. (2009). Stratejik Tedarik Zinciri Yönetimi’nde Bilişim Teknolojilerinin Kullanımı: Perakendecilik Sektöründe Bir Uygulama. İzmir.

Kasımoğlu, B. (2018). Endüstri 4.0’1n İntralojistik Sistemler Üzerine Getireceği Etkiler.

Kurtalan, M. (2009). Küresel Rekabet Ortamında İşletmelerde Teknoloji Geliştirme Birimlerinin Kurulması ve Teknoloji Yönetimi. Karaman.

Sarıkaya, N. T. (2014). Pazara Yeni Sunulan "Yüksek Teknoloji Ürünlerine” Yönelik Tüketici Tutumlarının TRI (Teknolojik Hazır Olma/İsteklilik) Endeksine Göre Analiz Edilmesi. Eskişehir.

Sedefçi, K. (2018). Endüstri 4.0 Bakış Açısıyla Nesnelerin İnterneti Ve Müşteri Deneyimi Açısından İncelenmesi. İstanbul. 